To the Editors:

\title{
Leptospira antibodies were present in the plasma part of a post-mortem clot
}

\author{
S M H M K Senanayake \\ Ceylon Medical Journal 2016; 61: 92 DOI: http://doi.org/10.4038/cmj.v61i2.8299
}

When leptospirosis or dengue is suspected during a post-mortem examination, blood is collected from a peripheral vein (femoral or neck) and immediately centrifuged to separate plasma from red blood cells. The plasma is tested for antibodies to confirm the diagnosis [1]. When whole blood is sent to the laboratory, the antibody test cannot be performed because of haemolysis. Clear plasma is required for the antibody test [2]. As a post-mortem change, several hours after death, plasma of peripheral blood appears pink because of haemolysis, and then becomes unsuitable for antibody tests. But postmortem clots can be collected from such bodies.

Post-mortem clots usually found in the heart has two parts. Red part is due to red blood cells and yellow part is due to plasma [3]. Post-mortem clots are not used for investigations because of the solid nature. But the yellow part of the post-mortem clot can be pressed (crushed) with clean gloved fingers and liquid plasma can be extracted easily. This yellow liquid plasma is clearer and thicker than plasma of centrifuged from femoral blood. Therefore in a patient who was suspected of death due to leptospirosis, both samples (clear plasma centrifuged femoral blood and extracted plasma from yellow part of the post-mortem clot) were tested for antibodies after obtaining consent from the next of kin. Both samples gave positive results of IgM antibodies of leptospirosis.

This single case suggests that the yellow part of post-mortem clot can be used to test antibodies [4]. Plasma from postmortem clots are clearer (free of haemolysis), easy to collect during the autopsy without centrifuging, and available even when peripheral blood is haemolysed.If plasma of post-mortem clots have similar levels of antibodies to the plasma of peripheral blood, post-mortem clots can be used for investigations. Then haemolysis after long post-mortem intervals will not be an obstacle for plasma antibody assays after autopsies.More research is necessary before this can be recommended as routine practice.

\section{Conflicts of interests}

There are no conflicts of interest.

\section{References}

1. Wilkemeyer I, Pruss A, Kalus U, Schroeter J. Comparative infectious serology testing of pre- and post-mortem blood samples from cornea donors. Cell Tissue Banking 2012; 13: 447-52.

2. Spitz WU, Spitz DJ. Spitz and Fisher's Medico-legal investigation of death. Fourth edition. Charles C Thomas 2006; p.128-41.

3. Jackowski C. Postmortem images of blood and its characteristics using MSCT and MRI. Int J Legal Med 2006; 120: 233-40.

4. Uekita I. Medico-legal investigation of chicken fat clot in forensic cases: immunohistochemical and retrospective studies. Legal Med (Tokyo) 2008; 10: 138-42.

Teaching Hospital, Anuradapura, Sri Lanka.

Correspondence: SMHMKS, e-mail: <senanayakekumara@yahoo.com>. Received 22June 2015 and revised version accepted 28 February 2016.

This is an open-access article distributed under the terms of the Creative Commons Attribution License, which permits unrestricted use distribution, and reproduction in any medium, provided the original author and source are credited. 